University of Nebraska - Lincoln

DigitalCommons@University of Nebraska - Lincoln

2016

New Records and Updated Checklist of Phlebotomine Sand Flies

(Diptera: Psychodidae) From Liberia

P. J. Obenauer

L. M. Rueda

S. S. El-Hossary

N. Watany

C. A. Stoops

See next page for additional authors

Follow this and additional works at: https://digitalcommons.unl.edu/usnavyresearch

This Article is brought to you for free and open access by the U.S. Department of Defense at

DigitalCommons@University of Nebraska - Lincoln. It has been accepted for inclusion in U.S. Navy Research by an authorized administrator of DigitalCommons@University of Nebraska - Lincoln. 


\section{Authors}

P. J. Obenauer, L. M. Rueda, S. S. El-Hossary, N. Watany, C. A. Stoops, L. S. Fakoli, F. K. Bolay, and J. W. Diclaro II 


\title{
New Records and Updated Checklist of Phlebotomine Sand Flies (Diptera: Psychodidae) From Liberia
}

\author{
P. J. Obenauer, ${ }^{1,2}$ L. M. Rueda, ${ }^{3}$ S. S. El-Hossary, ${ }^{3}$ N. Watany, ${ }^{3}$ C. A. Stoops, ${ }^{5}$ \\ L. S. Fakoli, ${ }^{6}$ F. K. Bolay, ${ }^{6}$ and J. W. Diclaro, ${ }^{4}{ }^{4}$
}

${ }^{1}$ U.S. Navy and Marine Corps Public Health Center Det., Centers for Disease Control and Prevention, Atlanta, 1600 Clifton Rd, 649, Bldg 23, office 9-117, Atlanta, GA 30329 (Yry3@cdc.gov), ${ }^{2}$ Corresponding author, e-mail: Yry3@cdc.gov, ${ }^{3}$ Walter Reed Biosystematics Unit, Entomology Branch, Walter Reed Army Institute of Research, Silver Spring, Imtidad Ramses Street, Adjacent to Abbassa Fever Hospital, Abbassa, Postal Code 11517 (ruedapol@si.edu; shabaanelhossary57@yahoo.com; Noha.Watany.eg@med.navy.mil), U.S. Naval Medical Research Unit No. 3, Cairo, Egypt (DiclaroJW@state.gov), ${ }^{5}$ Naval Medical Research Unit No. 6, Lima, Peru, 3230 Lima, PI, Washington, DC, 20521-3230 (craig.a.stoops.mil@mail.mil), and 'iberian Institute for Biomedical Research, P.0. Box 31, Charlesville, Margibi County, Monrovia, Liberia (lawfako2008@yahoo.com; bolayf@Ir.afro.who.int)

Received 18 November 2015; Accepted 23 December 2015

\begin{abstract}
Phlebotomine sand flies from three counties in Liberia were collected from January 2011 to July 2013. In total, 3,118 sand flies were collected: 18 species were identified, 13 of which represented new records for Liberia. An updated taxonomic checklist is provided with a brief note on sand fly biology, and the disease vector potential for species is discussed.
\end{abstract}

Key words: Leishmaniasis, Phlebotomus, Sergentomyia, West Africa

Phlebotomine sand flies are fragile, nocturnally active insects with blood-feeding females that serve as important vectors of Leishmania, Bartonella bacilliformes, and a number of arboviruses across the Old and New World (Alexander 2000, Ready 2013). The sand fly fauna in Liberia has rarely been studied, and little is known about the role that certain species may play in the transmission of leishmaniasis and other diseases. Located along the West African coast, Liberia encompasses $110,000 \mathrm{~km}^{2}$, bordering Sierra Leone to the north, Guinea to the northeast, and Côte D'Ivoire to the east. In the western forest belt of the Afrotropical Biotic Region, Liberia is characterized primarily by mangrove swamps along the coast, rolling hills, and dense tropical forests (Stojanovich and Scott 1966). According to Seccombe et al. (1993) and the Walter Reed Biosystematics Unit [WRBU] (2015 www.sandflycatalog.org), only five species of phlebotomines have been recorded from Liberia. Until this study, many more species of sand flies were suspected of existing in Liberia but had not been identified. As part of a larger mosquito surveillance study (Obenauer et al. 2013), we collected sand flies using various types of light traps and identified them to update sand fly records for the country.

\section{Materials and Methods}

Sand flies were surveyed from three counties in Liberia during 15 site visits from January 2011 to July 2013. Common flora throughout the sites included oil palms (Elaeis guineensis Jacquin), coconut palms (Cocus nucifera L.), silk cotton (Ceiba pentandra L.), rubber trees (Heva brasiliensis Müller Argoviensis), giant bamboo (Bambussa oldhamii Munro), and cassava (Manihot esculenta Crantz). Sand fly adults were collected using the Centers for Disease Control and Prevention (CDC) miniature light trap (model 512, John W. Hock Company, Gainesville, FL), the 4-W miniature ultraviolet (UV) CDC light trap (Bioquip Products, Rancho Dominguez, CA), and the UV light-emitting diodes (LED) light trap (Bioquip Products). Traps were suspended along a transect $20 \mathrm{~m}$ apart from each other and supplemented with attractants including the synthetic BG-Lure (Biogents, Germany) and carbon dioxide generated from fermented yeast (Obenauer et al. 2013) to improve catches. Sand fly specimens were frozen in a dry ice cooler for $1 \mathrm{~h}$, enumerated, and placed into $1.5 \mathrm{-ml}$ plastic microcentrifuge tubes containing a $75 \%$ ethanol solution. Sand flies were slide-mounted, sexed, and identified to species using pertinent literature (Abonnenc and Minter 1965, Abonnenc 1972, Lewis 1982, Lane 1986, Davidson 1990). The DNA was extracted from the alimentary canals from Phlebotomus species using QIAGEN DNV Mini Kit (QIAGEN, Valencia, CA) and tested for Leishmania tropica using real-time polymerase chain reaction (PCR) and PCR-restriction fragment length polymorphism as previously described (Villinski et al. 2008).

Nomenclaturally, we use the abbreviations proposed by Marcondes (2007) for genera and subgenera of Phlebotominae. Voucher specimens of all species collected from Liberia were sent to the U.S. Army WRBU, Smithsonian Institution, Suitland, MD, for species confirmation and to permanently deposit in the museum. To 
update the sand fly list, an extensive review of the literature was conducted for sand flies of Liberia using the WRBU catalog (www. sandflycatalog.org), VectorMap 2015 (www.vectormap.org), and the Armed Forces Pest Management Board Literature Retrieval Service (AFPMB-LRS 2015; http:afpmb.org/content/welcome-litera ture-retrieval-system).

\section{Results and Discussion}

In total, 3,118 sand flies representing 18 species in two genera (Phlebotomus and Sergentomyia) were collected in Lofa, Margibi, and Montserrado counties. From these collections, 13 species were determined to be new records for Liberia (Table 1). Table 2 gives an updated taxonomic checklist of phlebotomine species known from Liberia. Our survey yielded four species of genus Phlebotomus belonging to three subgenera: Adlerius (one sp.), Anaparaphlebotomus (one sp.), and Paraphlebotomus (two spp.). Our collections of genus Sergentomyia comprised 14 species in three subgenera: Grassomyia (one sp.), Neophlebotomus (three species), Parrotomyia (three spp.), Sergentomyia (four spp.), and three ungrouped species. Some of our specimens had damaged or missing diagnostic body parts, so could not be identified to species level, including the following taxa: Sergentomyia (Grassomyia), one female; Se. (Neophlebotomus), two females; Se. (Sergentomyia), one male; and Se. (ungrouped), one male and one female.

From 2011-2013, the greater numbers of sand flies were collected during May-August (Fig. 1), exhibiting a major peak in May 2012. The coastal area of Liberia received an average of $462 \mathrm{~cm}$ of annual precipitation, the greatest amount occurring during the rainy season from May to September (Climatemps 2015). Phlebotomus (Paraphlebotomus) sergenti Parrot, Phlebotomus (Paraphlebotomus) kazeruni Theodor \& Mesghali, and Phlebotomus (Adlerius) arabicus Theodor were only collected from Montserrado County. Sergentomyia (Grassomyia) squamipleuris Newstead, a new species for Liberia, was the predominant species of sand fly collected, comprising over $30 \%$ of the catch (Table 1). In Africa, similar

Table 1. Phlebotomine sand flies collected from three counties of Liberia from January 2011 to July 2013

\begin{tabular}{|c|c|c|}
\hline Species & Counties & Total $(\%)$ \\
\hline Sergentomyia squamipleuris Newstead ${ }^{a}$ & Lofa, Margibi & $951(30.5)$ \\
\hline Se. africana Newstead $^{a}$ & Lofa & $454(14.6)$ \\
\hline Se. schwetzi Adler, Theodor, Parrot & Lofa & $373(12.0)$ \\
\hline Se. dureni Parrott & Lofa & $338(10.8)$ \\
\hline Se. simillima Newstead ${ }^{a}$ & Lofa & $288(<0.1)$ \\
\hline Se. bedfordi Newstead ${ }^{a}$ & Lofa & $213(<0.1)$ \\
\hline Se. collarti Adler, Theodor, and Parrot ${ }^{a}$ & Lofa & $129(<0.1)$ \\
\hline Se. dissimillima Abonnenc ${ }^{a}$ & Lofa & $118(<0.1)$ \\
\hline Se. crosarai Parrot and Wanson ${ }^{a}$ & Lofa, Margibi & $108(<0.1)$ \\
\hline Se. impudica Abonnenc & Lofa & $84(<0.1)$ \\
\hline Pblebotomus rodhaini Parrot & Lofa & $23(<0.1)$ \\
\hline Se. ingrami Newstead $^{a}$ & Lofa & $17(<0.1)$ \\
\hline Se. eremitis Parrot \& Bouquet de Joliniere ${ }^{a}$ & Lofa & $8(<0.1)$ \\
\hline Se. moreli Abonnenc and Hamon ${ }^{a}$ & Lofa & $6(<0.1)$ \\
\hline Se. antennata Newstead & Lofa, Margibi & $4(<0.1)$ \\
\hline Ph. sergenti Parrot $^{a}$ & Montserrado & $2(<0.1)$ \\
\hline Ph. Kazeruni Theodor \& Mesghali ${ }^{a}$ & Montserrado & $1(<0.1)$ \\
\hline Ph. arabicus Theodor $^{a}$ & Montserrado & $1(<0.1)$ \\
\hline
\end{tabular}

\footnotetext{
${ }^{a}$ New country record.
}

Species listed in descending order, based on the total numbers of each species collected. observations were made by Lewis (1971), who noted that light traps caught high numbers of Se. squamipleuris compared with other sand fly species. Although not known to be disease vectors, Sergentomyia (Sergentomyia) schwetzi Adler, Theodor, and Parrot and Sergentomyia (Parrotomyia) africana Newstead are anthropophilic (Lewis 1971, Lewis and Murphy 1965). Both species were collected in large numbers, comprising $26 \%$ of the catch (Table 1 ). A wellknown exophilic species, Se. schwetzi, has been collected predominantly from many peridomestic habitats throughout West Africa, especially communities with many dogs (Anderson et al. 2011, Senghor et al. 2011).

Leishmaniasis is considered endemic in West Africa, with reported cases in Mali, Nigeria, Senegal, Chad, Mauretania, Gambia, and Ghana (Boakye et al. 2005, Anderson et al. 2011). According to Cahill (1968), several intensive studies conducted between 1910 and 1950 determined that cutaneous leishmaniasis was limited to arid regions between 10 and 20 degrees north latitude, while visceral leishmaniasis was focused in Gabon, Democratic Republic of the Congo, Angola, and Nigeria. Human cases of dermal leishmaniasis in Ho District of Ghana have recently been attributed to the

Table 2. Updated checklist of Phlebotomine sand fly species from Liberia

\begin{tabular}{|c|c|}
\hline Species & Reference \\
\hline $\begin{array}{l}\text { Phlebotomus (Adlerius) arabicus Theodor, } \\
1953^{a}\end{array}$ & $\mathrm{X}^{b}$ \\
\hline $\begin{array}{l}\text { Phlebotomus (Anaphlebotomus) rodhaini } \\
\text { Parrot, } 1930\end{array}$ & S, W, X \\
\hline $\begin{array}{l}\text { Phlebotomus (Paraphlebotomus) kazeruni } \\
\text { Theodor and Mesghali, } 1964^{a}\end{array}$ & $\mathrm{X}$ \\
\hline $\begin{array}{l}\text { Phlebotomus (Paraphlebotomus) sergenti } \\
\text { Parrot, } 1917^{a}\end{array}$ & $\mathrm{X}$ \\
\hline $\begin{array}{l}\text { Sergentomyia (Grassomyia) squamipleuris } \\
\quad \text { Newstead, } 1912^{a}\end{array}$ & $\mathrm{X}$ \\
\hline $\begin{array}{l}\text { Sergentomyia (Neophlebotomus) collarti Adler, } \\
\text { Theodor, and Parrot, } 1929^{a}\end{array}$ & $\mathrm{X}$ \\
\hline $\begin{array}{l}\text { Sergentomyia (Neophlebotomus) dureni Parrot, } \\
1934\end{array}$ & $\mathrm{~S}, \mathrm{~W}, \mathrm{X}$ \\
\hline $\begin{array}{l}\text { Sergentomyia (Neophlebotomus) ingrami } \\
\quad \text { Newstead, } 1914^{a}\end{array}$ & $\mathrm{X}$ \\
\hline $\begin{array}{l}\text { Sergentomyia (Parrotomyia) africana Newstead, } \\
\qquad 1912^{a}\end{array}$ & $\mathrm{X}$ \\
\hline $\begin{array}{l}\text { Sergentomyia (Parrotomyia) crosarai Parrot } \& \\
\quad \text { Wanson, } 1946^{a}\end{array}$ & $\mathrm{X}$ \\
\hline $\begin{array}{l}\text { Sergentomyia (Parrotomyia) eremitis Parrot \& } \\
\text { Bouquet de Joliniere, } 1945^{a}\end{array}$ & $\mathrm{X}$ \\
\hline $\begin{array}{l}\text { Sergentomyia (Sergentomyia) antennata } \\
\quad \text { Newstead, } 1912\end{array}$ & $\mathrm{~S}, \mathrm{~W}, \mathrm{X}$ \\
\hline $\begin{array}{l}\text { Sergentomyia (Sergentomyia) bedfordi } \\
\quad \text { Newstead, } 1914^{a}\end{array}$ & $\mathrm{X}$ \\
\hline $\begin{array}{l}\text { Sergentomyia (Sergentomyia) impudica } \\
\quad \text { Abonnenc, } 1968\end{array}$ & $\mathrm{~S}, \mathrm{~W}, \mathrm{X}$ \\
\hline $\begin{array}{l}\text { Sergentomyia (Sergentomyia) schwetzi Adler, } \\
\text { Theodor, and Parrot, } 1929\end{array}$ & S, W, X \\
\hline $\begin{array}{l}\text { Sergentomyia (Ungrouped) dissimillima } \\
\quad \text { Abonnenc, } 1972^{a}\end{array}$ & $\mathrm{X}$ \\
\hline $\begin{array}{l}\text { Sergentomyia (Ungrouped) moreli Abonnenc \& } \\
\quad \text { Hamon, } 1958^{a}\end{array}$ & $\mathrm{X}$ \\
\hline $\begin{array}{l}\text { Sergentomyia (Ungrouped) simillima Newstead, } \\
1914^{a}\end{array}$ & $\mathrm{X}$ \\
\hline
\end{tabular}

${ }^{a}$ New species record for Liberia (= 13 out of 18 total reported species).

${ }^{b}$ S (Seccombe et al. 1993), W (WRBU 2015), and X (this survey). 


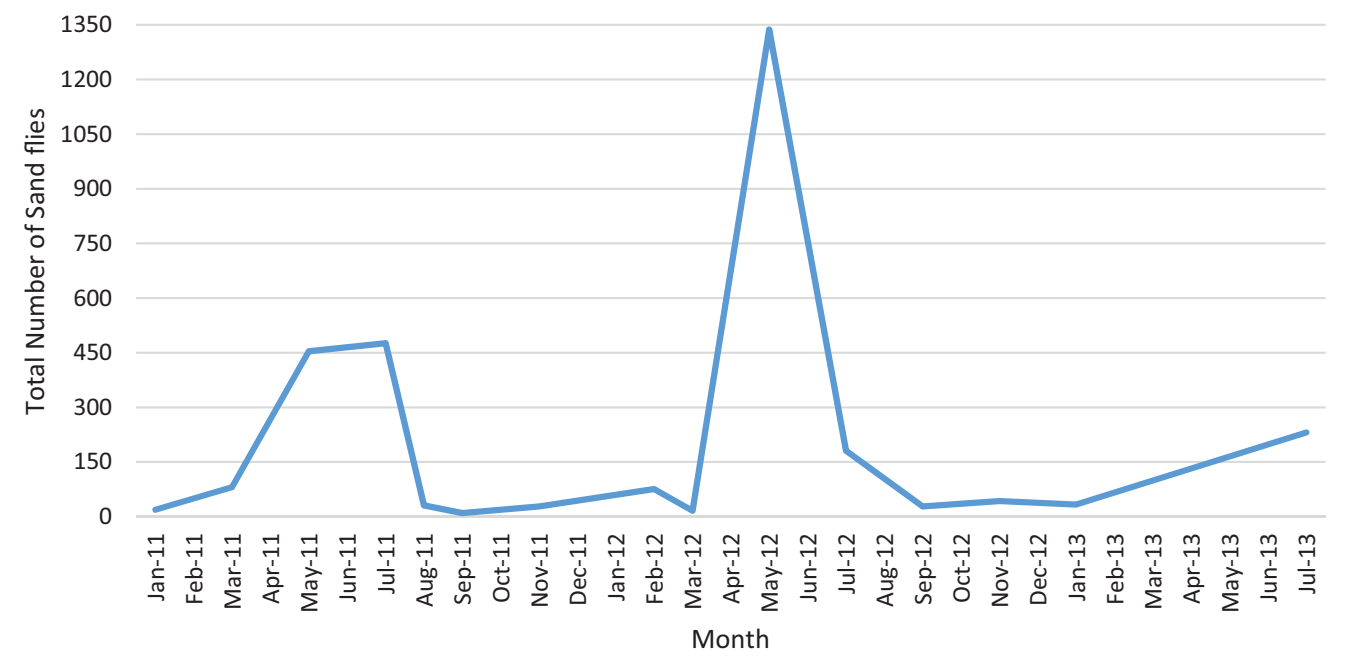

Fig. 1. Seasonal abundance of Phlebotomine sand flies collected from three counties of Liberia (January 2011-July 2013).

Leishmania enriettii complex (Kwakye-Nuako et al. 2015), but we found no reports of any leishmaniasis from Liberia.

Of the 18 sand fly species collected in our study in Liberia, two species $P h$. (Adl.) arabicus and $P h$. (Par.) sergenti have been implicated as vectors of Leishmania parasites in Africa (Ready 2013). Phlebotomus sergenti represents a proven vector for anthroponotic cutaneous leishmaniasis (ACL). However, Leishmania (Leishmania) tropica (Wright), the causative organism for ACL, is focused in drier parts of West Africa and transmitted primarily by Phlebotomus (Phl.) duboscqi Neveu-Lemaire (Killick-Kendrick 1999). In his review of the Phlebotomine sand flies, Ready (2013) noted that $P h$. sergenti, Ph. arabicus, and Phlebotomus (Lar.) guggisbergi Kirk and Lewis are proven vectors of Le. tropica in Africa. A new record for Liberia $\mathrm{Ph}$. sergenti was collected on the outskirts of downtown Monrovia (Montserrado County), which is not unexpected because of its reported propensity for peridomestic habitats and human hosts (Ready 2013). Two Ph. sergenti specimens in our collections tested negative for the presence of Le. tropica; however, it could be a potential vector for ACL and future investigations are warranted to determine its vector status in Liberia. Moreover, in Senegal, Senghor et al. (2011) hypothesized that Se. schwetzi might be a potential vector of canine leishmaniasis, challenging the dogma that only Phlebotomus species are capable of transmitting Leishmania in the Old World. Sergentomyia (Sergentomyia) bedfordi Newstead and Se. (Par.) africana are also new records for Liberia, and while not reported disease vectors, they are worth mentioning for consistently biting humans in Kenya and Sudan, respectively (Lewis and Murphy 1965, Seccombe et al. 1993).

While we did not use a variety of trapping methods to elucidate sand fly microhabitats such as tree holes or vegetation types, surveillance conducted in the Gambia demonstrated that Se. squamipleuris is typically collected by light traps in areas with permanently moist soil (Lewis and Murphy 1965). Additionally, their study showed that more sand fly species were collected in fields of oil palms and rice than in other habitats. Similarly, the majority of our collected sand flies were from sites that were adjacent to rice field or savannah-type environments. We only surveyed sand flies in three counties of Liberia, and more comprehensive sand fly surveillance is warranted from the remaining 11 counties to provide a better assessment of the sand fly fauna throughout the country. In addition, future collections should use different sampling methods to collect a possibly wider range of species, and to determine anthropophilic versus zoophilic behavior and exophily versus endophily, for inferring risks of Leishmania pathogen transmission to the people of Liberia.

\section{Acknowledgments}

We thank Maria Badra for her assistance with logistical support of all personnel and materials pertaining to this study, and El-Shaimaa Nour El-Din, Rania Kaldas, Emad Fawaz, and Mahmoud Abdel-Dayem for their help in processing, identifying, and testing sand fly specimens. We thank the U.S. Navy Entomology Center of Excellence (NECE) staff for their assistance with collecting sand flies. We are grateful to the support staff of the Liberian Institute for Biomedical Research (LIBR), Monrovia, Liberia, for assisting and executing this study. A special thanks to Graham White and Seth Irish for providing a critical review of this manuscript. The views expressed in this article are those of the authors and do not necessarily reflect the official policy or position of the Department of the Navy, the Department of the Army, and the Department of Defense, nor the U.S. Government. This work was funded by the Department of Defense's Global Emerging Infections System (GEIS) unit work numbers C0436-11-N3 and C0549-12-N3. This work was prepared as part of our official duties. Title 17 U.S.C. $\$ 105$ provides that "Copyright protection under this title is not available for any work of the United States Government." Title 17 U.S.C. $\$ 101$ defines a U.S. Government work as a work prepared by a military service member or employee of the U.S. Government as part of that person's official duties. Furthermore, this research was performed under a Memorandum of Understanding between the Walter Reed Army Institute of Research and the Smithsonian Institution, with institutional support provided by both organizations.

\section{References Cited}

Abonnenc, E. 1972. Les Phlebotomes de la region Ethiopienne (Diptera, Psychodidae). Memoires Office de la Recherche Scientifique et Technique Outre-Mer (ORSTOM), No. 55: 1-289.

Abonnenc, E., and D. M. Minter. 1965. Keys for the identification of sandflies of the Ethiopian region. Cahiers Office de la Recherche Scientifique et Technique Outre-Mer (ORSTOM), Ser. Entomol. Med. 5: 24-63.

Alexander, B. 2000. Sampling methods for phlebotomine sandflies. Med. Vet. Entomol. 14: 109-122.

Anderson, J. M., S. Samake, G. Jaramillo-Gutierrez, I. Sissoko, C. A. Coulibaly, B. Traoré, C. Souko, B. Guindo, D. Diarra, M. P. Fay, et al. 2011. Seasonality and prevalence of Leishmania major infection in Phlebotomus duboscqi Neveu-Lemaire from two neighboring villages in central Mali. PLoS Negl. Trop. Dis. 5: e1139. 
AFPMB-LRS. 2015. Armed forces pest management board literature retrieval system (AFPMB-LRS). (http:afpmb.org/content/welcome literature-re trieval-system) (accessed 22 October 2015)

Boakye, D. A., M. D. Wilson, and M. Kweku. 2005. A review of leishmaniasis in west Africa. Ghana Med. J. 39: 94-97.

Cahill, K. M. 1968. Clinical and epidemiological patterns of leishmaniasis in Africa. Trop. Geogr. Med. 20: 109-118.

Climatemps. 2015. (http://www.liberia.climatemps.com)

Davidson, I. H. 1990. Sandflies of Africa South of the Sahara: Taxonomy and systematics of the genus Sergentomyia, p. 35. Department of Medical Entomology, South African Institute for Medical Research, Johannesburg, South Africa.

Killick-Kendrick, R. 1999. The biology and control of Phlebotmine sand flies. Clin. Dermatol. 17: 279-289.

Kwakye-Nuako, G., M. T. Mosore, C. Duplessis, M. D. Bates, N. Puplampu, I. Mensah-Attipoe, K. Desewu, G. Afegbe, R. H. Asmah, M. B. Jamjoom, et al. 2015. First isolation of a new species of Leishmania responsible for human cutaneous leishmaniasis in Ghana and classification in the Leishmania enriettii complex. Int. J. Parasitol. 45: 679-684.

Lane, R. P. 1986. The sandflies of Egypt (Diptera: Psychodidae). Bull. Br. Mus. Natl. His. 52: 286-291.

Lewis, D. J., and D. H. Murphy. 1965. The sand-flies of the Gambia (Diptera: Phlebotominae). J. Med. Entomol. 1: 371-376.

Lewis, D. J. 1971. Phlebotomid sandflies. Bull. World Health Org. 44: 535-551. Lewis, D. J. 1982. A taxonomic review of the genus Phlebotomus (Diptera: Psychodidae). Bull. Br. Mus. Nat. Hist. 45: 121-209.

Marcondes, C. B. 2007. A proposal of generic and subgeneric abbreviations for Phlebotominae sandflies (Diptera: Psychodidae: Phlebotominae) of the world. Entomol. News 118: 351-356.
Obenauer, P. J., M. S. Abdel-Dayem, C. A. Stoops, J. T. Villinski, R. Tageldin, N. T. Fahmy, J. W. Diclaro II, and F. Bolay. 2013. Field responses of Anopheles gambiae complex (Diptera: Culicidae) in Liberia using yeastgenerated carbon dioxide and synthetic lure baited light traps. J. Med. Entomol. 50: 863-870.

Ready, P. D. 2013. Biology of Phlebotomine sand flies as vectors of disease agents. Annu. Rev. Entomol. 58: 227-250.

Seccombe, A. K., P. D. Ready, and L. M. Huddleston. 1993. A catalogue of old world Phlebotomine sandflies (Diptera: Psychodidae, Phlebotominae) (Occasional Papers on Systematic Entomology). Intercept Ltd. Hampshire, UK.

Senghor, M. W., M. N. Faye, B. Faye, K. Diarra, E. Elguero, O. Gaye, A. Bañuls, and A. A. Niang. 2011. Ecology of phlebotomine sand flies in the rural community of Mont Rolland (Thiès Region, Senegal): Area of transmission of canine leishmaniasis. PLoS ONE 6: e14773.

Stojanovich, C. J., and H. G. Scott. 1966. Illustrated key to Anopheles mosquitoes of Liberia, p. 38. U.S. Department of Health Education and Welfare Public Health Service, Atlanta, GA.

VectorMap. 2015. VectorMap, walter reed biosystematics unit. Smithsonian Institution, Museum Support Center, Suitland, MD. (http://www.vector map.org/) (accessed 22 October 2015).

Villinski, J. T., J. D. Klena, M. Abbassy, D. F. Hoel, N. Puplampu, D. M. Boakye, and G. Raczniak. 2008. Evidence for a new species of Leishmania associated with focal disease outbreak in Ghana. Diagn. Microbiol. Infect. Dis. 60: 323-268.

(WRBU) Walter Reed Biosystematics Unit. 2015. Catalog of Subfamily Phlebotominae (Diptera: Psychodidae). Smithsonian Institution, Museum Support Center, Suitland, MD. (http://www.sandflycatalog.org/) accessed 22 October 2015). 